International Journal for Service Learning in Engineering

Vol. 5, No. 1, pp. 1-24, Spring 2010

ISSN 1555-9033

\title{
Validation Process for a Social Entrepreneurial Telemedicine Venture in East Africa
}

\author{
Aaron Fleishman \\ B.S., Chemical Engineering, May 2009 \\ Penn State University \\ University Park, PA 16802 \\ ajf200@gmail.com \\ Jason Milnes \\ Junior, College of Communications \\ Penn State University \\ University Park, PA 16802 \\ Jennifer Moreau \\ Senior, Department of Kinesiology \\ Penn State University \\ University Park, PA 16802
}

\author{
Julia Wittig \\ B.S., Biobehavioral Health, May 2009 \\ Penn State University \\ University Park, PA 16802
}

Andrew Baxter

B.S., Political Science, December 2008

Penn State University

University Park, PA 16802

\author{
Khanjan Mehta* \\ Senior Research Associate, ECS \\ Affiliate Faculty, SEDTAPP \\ College of Engineering, Penn State University \\ University Park, PA 16802 \\ khanjan@engr.psu.edu \\ * Corresponding Author
}

\begin{abstract}
Mashavu ("chubby-cheeked" in Swahili) is a telemedicine system under development that connects medical professionals around the world with people in developing communities in East Africa. Mashavu kiosks are computer-based systems that collect medical information including weight, body temperature, lung capacity, pulse rate, blood pressure, stethoscope rhythms, photographs and basic hygiene and nutrition information. Mashavu kiosks transmit this information over a cell-phone link to a secure internet website. Medical professionals and public health officials can view the patient's information and respond to the person/operator with recommendations. An imperative part of complex product design, especially when working in international contexts, is to gain validation. Validation ensures that the product being designed accurately fits the needs of the population for which it is being designed. The Mashavu team used methodologies from the world of engineering, business, and the social sciences to validate the concept, business plan, technology and usability of the system. This paper discusses the Mashavu venture and the methodologies employed for getting validation and uncovering the "sticky information" related to the East African context that is critical to the design and commercialization of the Mashavu telemedicine system.
\end{abstract}

Index Terms - humanitarian engineering, market validation, social entrepreneurship, telemedicine 
International Journal for Service Learning in Engineering

Vol. 5, No. 1, pp. 1-24, Spring 2010

ISSN 1555-9033

\section{InTRODUCTION AND CONTEXT}

\section{Humanitarian Engineering and Social Entrepreneurship at Penn State}

The College of Engineering at Penn State has numerous ongoing humanitarian engineering and social entrepreneurship (HESE) initiatives. ${ }^{1}$ The basic philosophy behind the initiatives is the convergence of concepts, disciplines, cultures, and countries towards a freer, fairer, friendlier, and more sustainable planet. HESE challenges students and faculty from across the campus to break down the barriers between their disciplines and truly collaborate to develop technology-based solutions to address the most compelling problems facing humanity today. The objective is to develop transformative social innovations and scalable business models to transform these technology solutions into sustainable and scalable ventures that enable and accelerate positive social change throughout the world.

A twelve-credit certificate program in Engineering and Community Engagement is offered to undergraduate students from all disciplines. The most important piece of the certificate program is participation in a technology-based social venture that is integrated into academics by way of the "eplum" model of student engagement. ${ }^{2}$ Systems thinking is emphasized in all the ventures and initiatives associated with HESE and applied where possible. ${ }^{9}$ During the Spring and Fall semesters of 2007, we studied various models of telemedicine in the developed and developing world with the objective of determining how a telemedicine system could be used to address health inequities in East Africa. This led to the conceptualization of a telemedicine system called Mashavu: Networked Health Solutions for the Developing World.

In order to design an appropriate system and implementation plan that actually addresses healthcare challenges on a micro and macro level in communities in northern Tanzania, it was essential to have a thorough understanding of healthcare challenges, available resources and how telemedicine might (or might not) work in the specific context. The majority of information needed was qualitative and related to the operating environment, specifically the social, economic and technological context. The results of the validation process would give the product development team a better understanding of how Mashavu needs to be designed so that it functions well and improves access to healthcare in East Africa. The kinds of validation sought by our team and the methodologies employed are the subject of this paper. A number of other distinct publications (cited in this paper) have been published or are in preparation by our team because it is simply not realistic to cover all the various aspects and observations in one paper. This project is a work-in-progress at a fairly large scale with about 162 students from over 28 disciplines across nine colleges participating in it over the last three years. However, work on Mashavu started with the conceptualization and validation of the project - which is the focus of this paper.

The first section of this paper discusses the potential for telemedicine and the Mashavu system. The second section discusses the technology innovation that makes Mashavu more applicable and realizable in the African context. The next section discusses the various kinds of validation sought by our team and the methodologies employed. This section also includes observations from fieldwork in Tanzania and how we are using the information gathered during the validation phase to ensure the venture's sustenance and success. The observations and lessons discussed in this paper are not based on scientific research. They are based solely on the authors' (and team's) experiences and bear the burden of their biases, prejudices and ideologies. The purpose of sharing these observations is to provide 
International Journal for Service Learning in Engineering

Vol. 5, No. 1, pp. 1-24, Spring 2010

ISSN 1555-9033

insight into the appropriate validation methodologies and practical intricacies of developing and commercializing (telemedicine) solutions in East Africa.

\section{Healthcare Challenges in East Africa}

Tanzania, like many developing countries in Sub-Saharan Africa, suffers from a severe lack of healthcare professionals. There is one doctor for every 50,000 people in Tanzania, compared to one doctor for every 384 people in the United States. Nearby countries in East Africa have similar challenges: Rwanda (1:22,501), Kenya (1:8,551), and Uganda (1:14,330). ${ }^{3}$ Provider shortages are likely to persist in many of these countries because they do not have the resources to train adequate numbers of medical personnel.

Access to care is further limited when people must travel long distances for basic medical care. Most clinics and major hospitals are located in and near urban areas. To reach the primary care facilities, people rely on public transportation systems like dala-dalas - a minibus share taxi that is the most common type of public transportation. Our validation efforts in Tanzania indicated that people travel upwards of two hours and spend over \$2 USD (almost two days income) on transportation just to reach the doctors. The combined cost of transportation and loss of income while making the trip causes many people to delay seeking medical care until a serious issue arises. The concept of preventive healthcare is mostly unknown in East Africa.

One demographic that is significantly affected is the expanding youth population in East Africa. There are more than 2.6 million orphans in Tanzania, comprising almost $7 \%$ of the population. ${ }^{4}$ Many live in orphanages with caregiver to child ratios as low as 1:30. For example, students at the Pennsylvania State University have worked with Good Hope Orphanage (Figure 1) in Usa River, Tanzania during service-learning trips over the last several years. The children at Good Hope Orphanage do not see a doctor on a regular basis because taking a child to the doctor costs a significant amount of time and money. Our team has witnessed first-hand situations where preventable and minor illnesses spiraled into potentially life-threatening conditions on multiple occasions, both at the orphanage and within individual households.

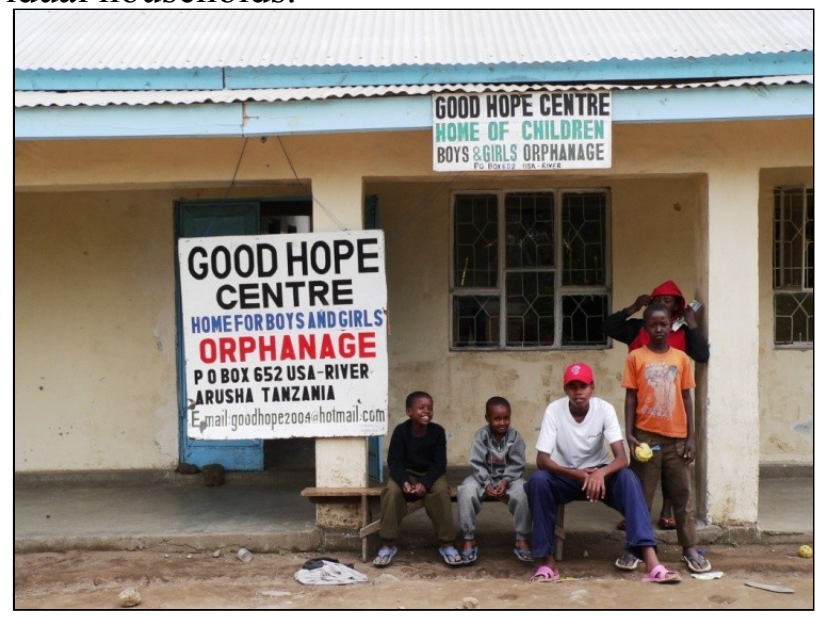

FigURE 1

Good Hope Orphanage in Usa River, Tanzania 
International Journal for Service Learning in Engineering

Vol. 5, No. 1, pp. 1-24, Spring 2010

ISSN 1555-9033

\section{The Potential of Telemedicine}

Communications technologies and telemedicine have the potential to help overcome some of the health care challenges in remote regions. Cell phones are rapidly transforming the African continent. It is estimated that $97 \%$ of the people in Tanzania have access to a cell phone. ${ }^{5}$ Mobile phone coverage in Tanzania already covers most outlying rural areas, as seen in Figure 2. Computers are gradually making their way into rural Africa. ${ }^{6}$ The combination of these technologies can connect patients in remote developing communities with doctors around the world. We talked informally with about twenty-five U.S. doctors and found that many of them and their colleagues are interested in performing outreach in developing communities. A significant hurdle is that many cannot make commitments to long-term international assignments, like those required by Doctors Without Borders. ${ }^{7}$ Short-term mission trips are very expensive and are not sustainable solutions.

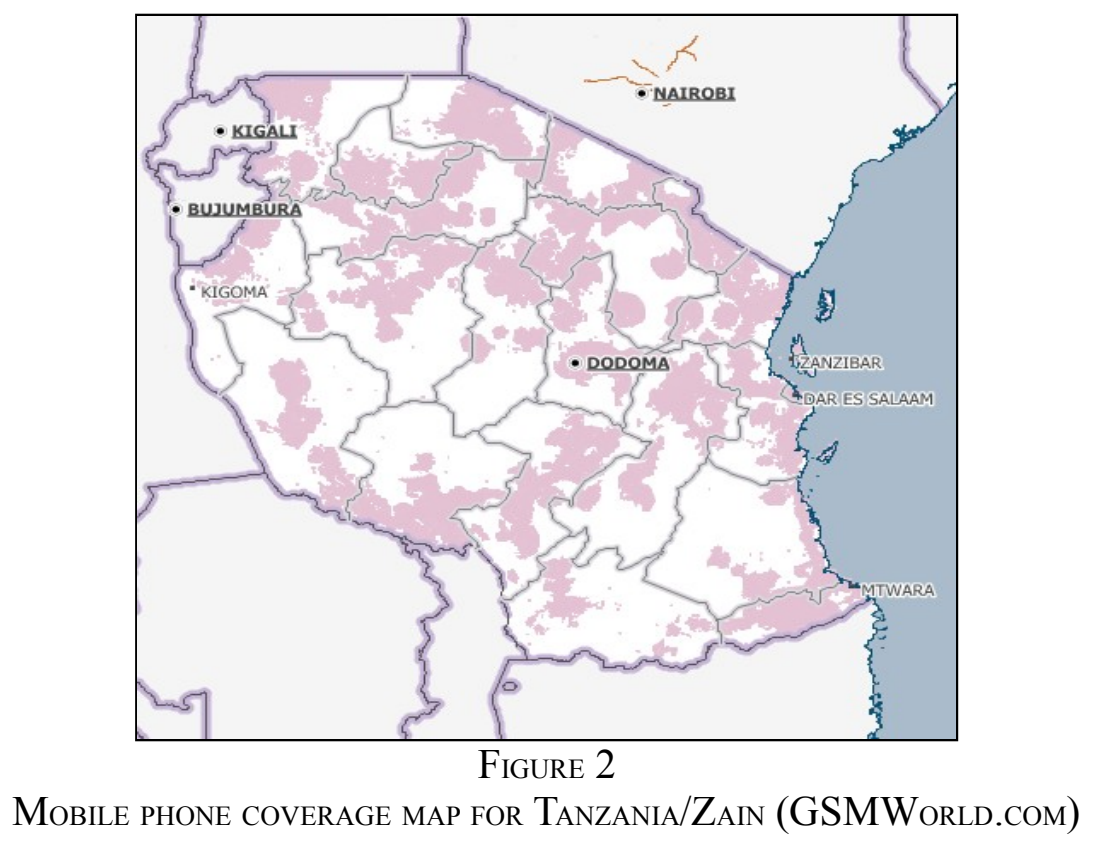

\section{Mashavu - Networked Health Solutions for the Developing World}

Mashavu is a telemedicine system that enables medical professionals around the world to connect with patients in the developing world using modern technology and existing communications infrastructure (Figure 3). Trained operators at Mashavu kiosks in developing communities collect essential medical information including weight, body temperature, lung capacity, blood pressure, pulse, stethoscope rhythms, photographs, and information about basic hygiene and nutrition. Each kiosk operator works as a facilitator during checkups. Patients are encouraged to interact with the user-friendly software and hardware. At each individual checkup, the patient is asked questions and given standard tests to monitor their health and nutrition. 


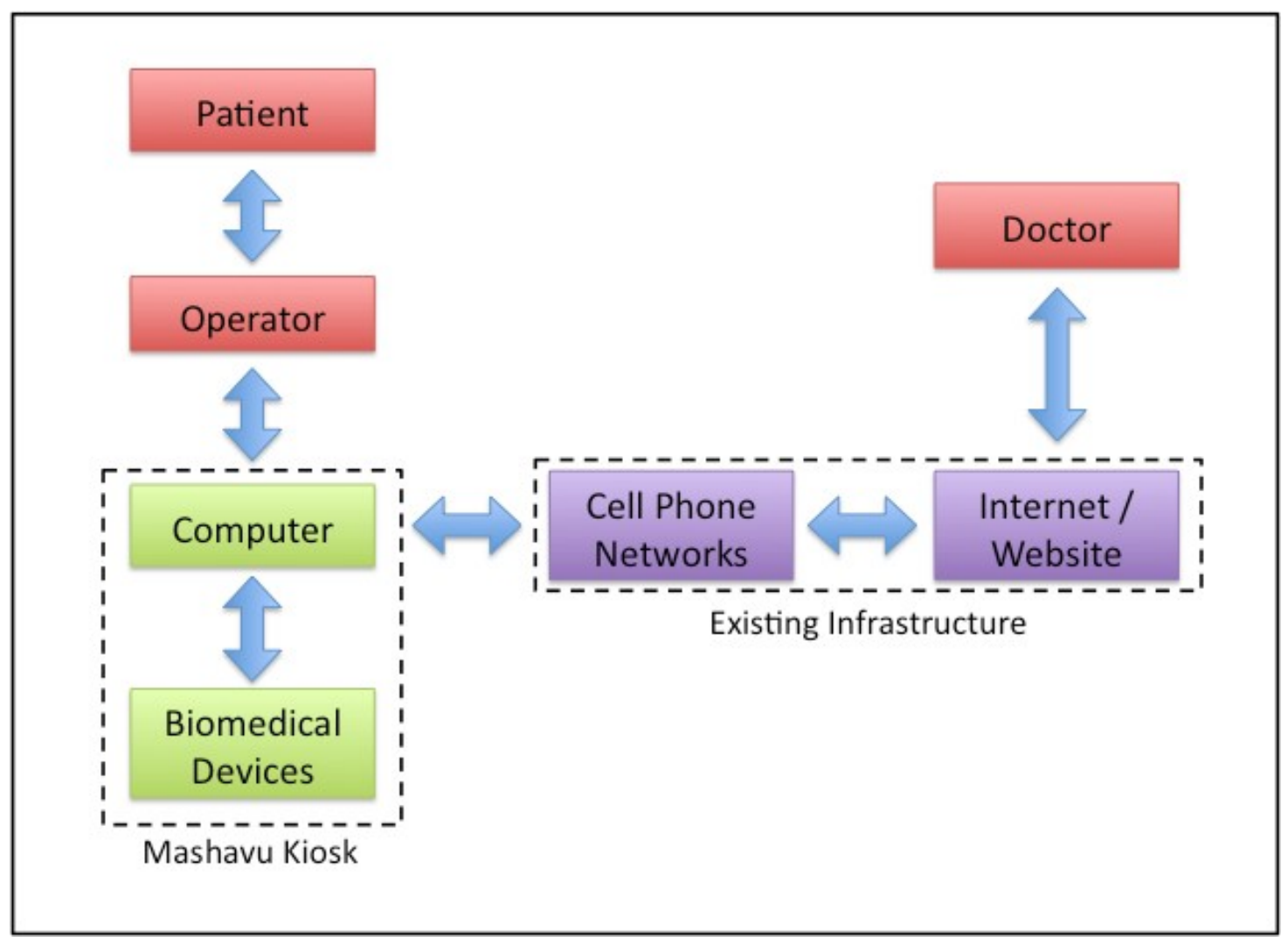

FIGURE 3

Block diagram of Mashavu system

A web server aggregates the information from various Mashavu kiosks over a cell phone link and displays it on a secure website. Medical professionals anywhere in the world can view the patient's information and respond to the patient and the nearest doctor(s) with their recommendations. The patients follow up directly with the local doctor, if necessary. In some cases, the system serves as a link between the patients and local doctors. The medical professionals can review community health statistics in order to evaluate any general health trends or possible epidemics in the area. This information can be made anonymous and shared with local community leaders so that health priorities are addressed effectively.

Our team has summarized the objectives that the Mashavu venture hopes to achieve into four overarching goals. These over-arching goals are:

- Improved Access to Healthcare

- Active Community Health Education

- Socio-economic Development through Micro-enterprise

- Developing Students into Entrepreneurial Global Citizens

\section{TeChNOLOGY InNovation}


International Journal for Service Learning in Engineering

Vol. 5, No. 1, pp. 1-24, Spring 2010

ISSN 1555-9033

Prior to visiting Tanzania, our team designed a proof-of-concept prototype for the Mashavu system using commercial-off-the-shelf (COTS) devices. A weighing scale, blood pressure monitor, thermometer and a camera were connected to a computer over USB and Serial ports (Figure 4). COTS biomedical monitoring devices are made by a number of vendors primarily for geriatric or rural care in developed nations. The system built using COTS devices including a weighing scale, blood pressure monitor, thermometer and camera costs about $\$ 620$, not including the computer and cell phone. During the validation phase (explained in this paper), our team realized that these devices are too expensive and not rugged enough for the harsh environment of Tanzania. To overcome this challenge, our team is in the process of developing virtual instrumentation-based biomedical devices with an emphasis on modular, rugged, and affordable design. We are striving to design the Mashavu system with a thermometer, blood pressure monitor, weighing scales for adults and infants, spirometer, pulse oximeter, electronic stethoscope and a camera for \$120. This price includes a Data Acquisition (DAQ) device, but excludes the cost of a computer and compatible cell phone with plan.

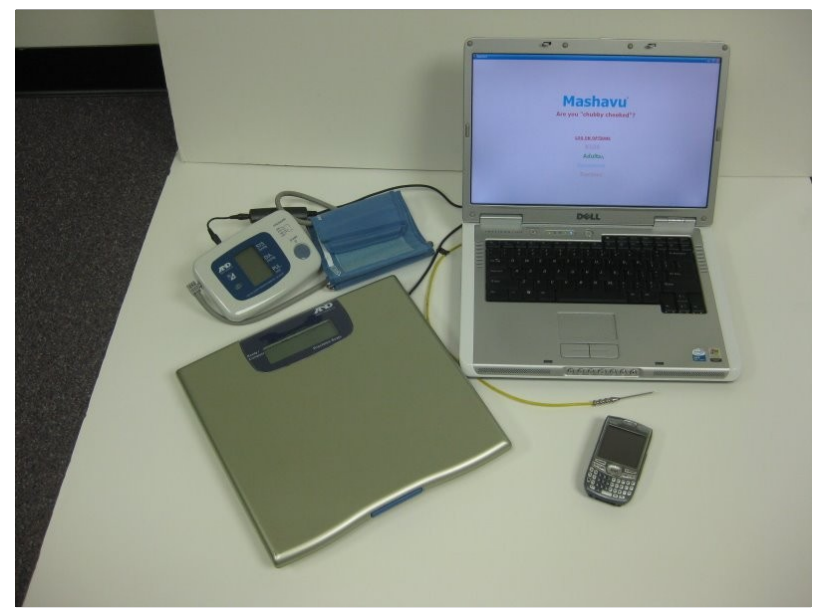

FIGURE 4

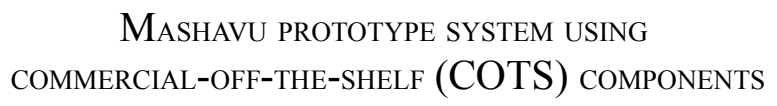

This significant cost reduction is achievable through virtual instrumentation. The COTS devices embed the primary sensor, signal conditioning, user display and networking support on the device itself. The Mashavu devices consist of only a sensor and the minimal essential hardware around it. The sensor output is digitized by a DAQ device shared by all the devices (Figure 5). The signal conditioning and user display is handled by software on the computer, turning the entire computer into a virtual instrument (VI). Hardware is expensive and repairing the devices is unrealistic. However, computer software is cheap. It requires little on-site maintenance and can be easily upgraded through the existing Internet connection. Some of the hardware can be locally manufactured, and only the basic sensors, which are widely available and mostly inexpensive, have to be imported. Virtual instrumentation-based designs and prototypes already exist for most basic biomedical diagnostic devices. We are adapting and redesigning these existing devices to meet our design requirements. All of the hardware designs and accompanying software, including source code, will be publicly available online for people to build upon for their own uses. Primary support for the software being used on 
Mashavu kiosks will be handled by a for-profit or non-profit entity, as described in the preliminary business plan.

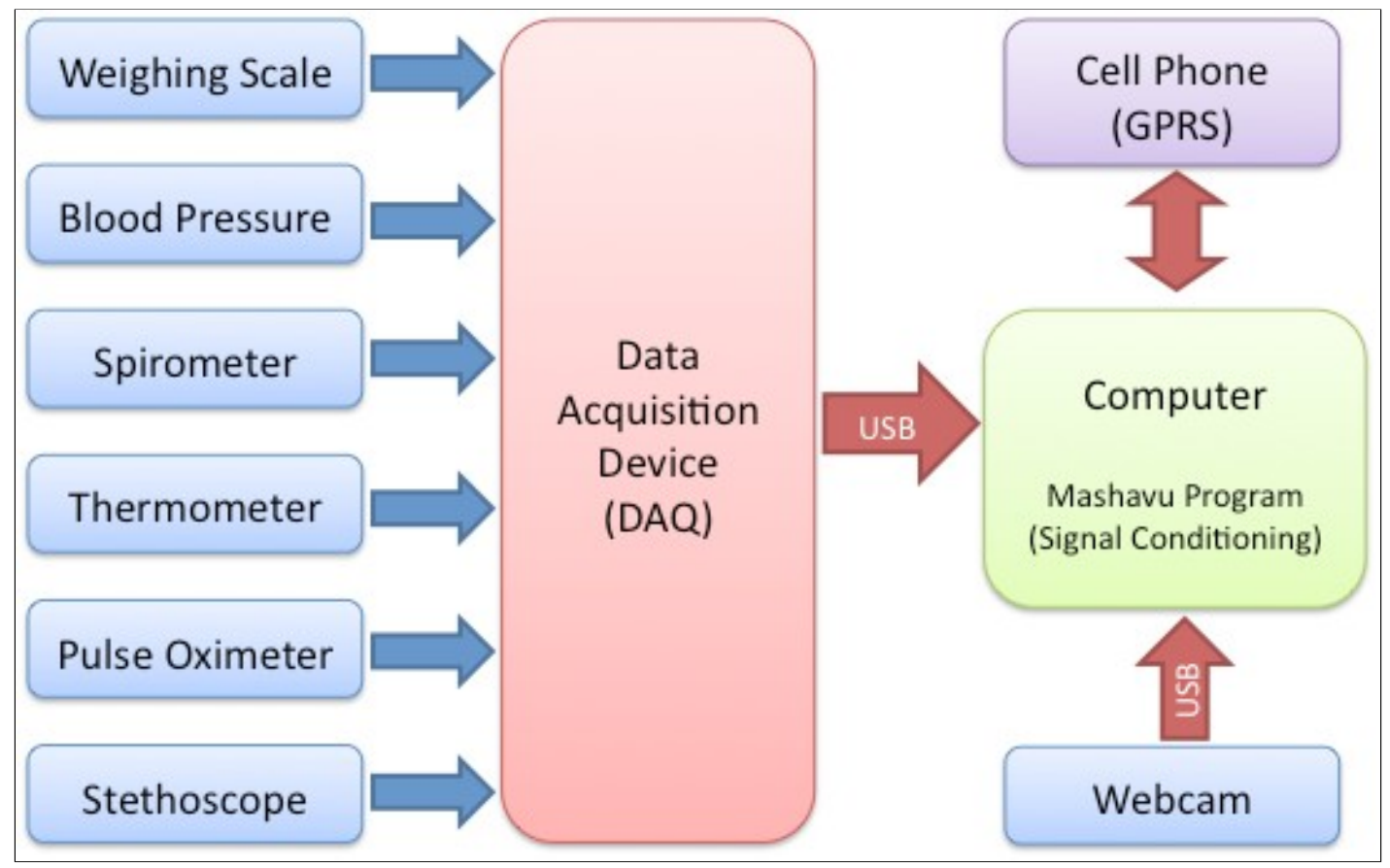

FIGURE 5

BLOCK DiAgram For VirTual INSTRUMENT BASED DEVICES

Biomedical devices connected to the DAQ device communicate with the computer through a USB port. Mashavu kiosk software is used to manage patient records and communicate with the Mashavu web servers. A secure Internet connection to transmit data is made possible using a cell phone. Most modern cell phones are able to connect to the Internet through a mobile gateway using a service called General Packet Radio Service (GPRS). This technology allows cell phones to receive email, browse websites, and upload data. By connecting a cell phone to the computer using a USB cable, a setup known as tethering, the computer can utilize the cell phone's Internet connection. GPRS is widely offered across East Africa by Zain, Vodacom, Orange, and Safaricom. The Mashavu web site features an intuitive user interface with secure login to verify the identity of doctors and protect patient privacy. The Mashavu system can facilitate three-way communication between the Mashavu kiosk, the local doctor (who is few hours away) and a specialist, who could be in the closest major city or anywhere in the world (Figure 6). 


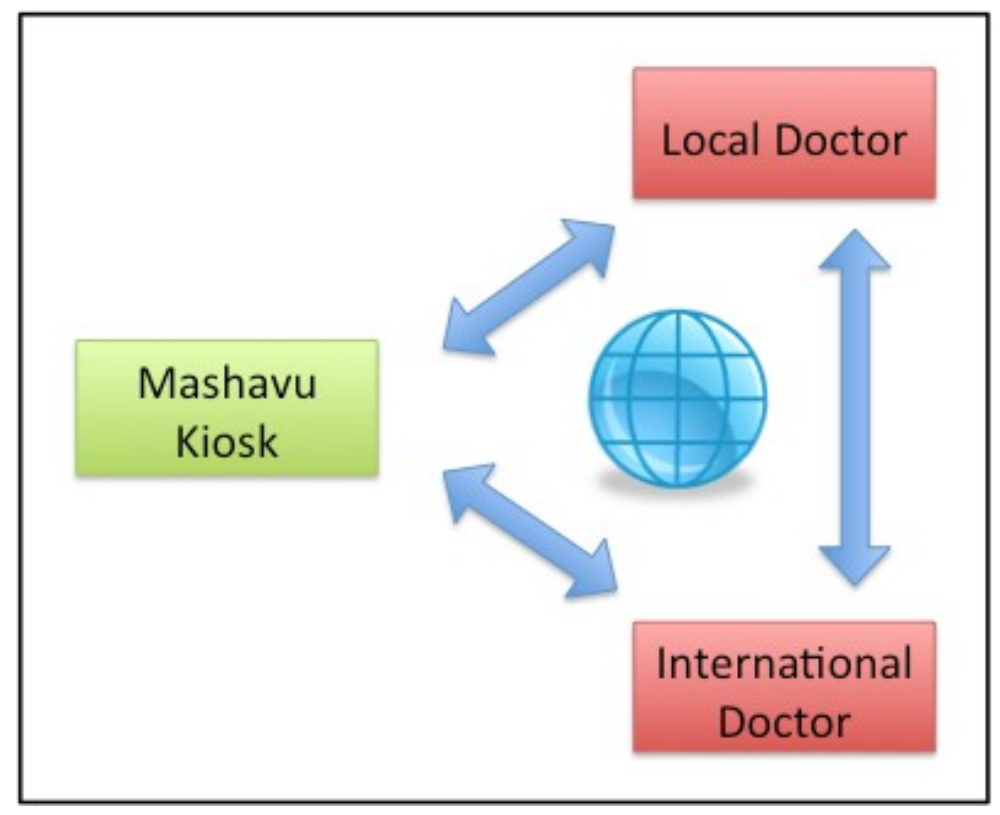

FIGURE 6

MashaVu THREE-WAY NETWORK Diagram

\section{Preliminary Business Plan(s)}

The approximate cost price of each Mashavu system will be about $\$ 120$ and selling price will be around \$200, excluding an appropriate cell phone and computer. Customers (i.e. orphanages, community centers, churches, clinics, entrepreneurs) will purchase the system with help from microfinance organizations. They will charge community members a small fee to use the service. We also considered other models such as having doctors around the world e-adopt children on Mashavu - which makes them responsible for looking over the child's health statistics regularly. Charging large organizations like UN agencies, WHO or research organizations for the de-identified data was another potential business model. These were ideas based on our literature review or initial conversations with concerned stakeholders and needed more validation. A specific question our team sought to explore was how the system can be made affordable to the poorest segments of society.

\section{Other Telemedicine Initiatives and Competitive Advantage}

There are a number of telemedicine companies in the United States serving geriatric needs and rural communities. These comprehensive systems are fairly expensive and do not meet the diagnosis and care needs in developing countries. We studied telemedicine models in India, Cambodia, East Africa, and other countries and discovered the following: ${ }^{8}$

- Most models are based on verbal communication between doctors and patients (over cell phones) and include photographs only in some cases. They do not include any kind of biomedical devices to provide more information to the doctors. 
International Journal for Service Learning in Engineering

Vol. 5, No. 1, pp. 1-24, Spring 2010

ISSN 1555-9033

- Some solutions focus on connecting rural clinics to urban clinics (i.e. AMREF in East Africa) but very few systems provide basic community-level health services that connect individuals to larger clinical settings.

- Very few telemedicine systems are tightly integrated with an electronic medical record system to track patient's health numbers and history.

- Very few systems embed traditional medicine based on indigenous knowledge (which is widely practiced in these locations).

- There is significant literature on successful telemedicine studies. Most of them were scientific experiments and not business ventures - they lacked an entrepreneurial component to ensure economic sustainability.

Mashavu combines patient inputs with personal biomedical information (leading to better diagnosis/recommendation), employs a holistic approach by engaging and educating community members in the process of monitoring their own health, and sustains itself in low-resource areas. The system uses rugged and inexpensive biomedical sensors and existing telecommunications infrastructure. Our team is taking an entrepreneurial approach to making Mashavu economically sustainable, and we have cultivated collaborations to implement Mashavu and to develop an effective process for replication and scaling up.

\section{Product Validation \& "Sticky" Information}

Validation is the process of ensuring that the design team understands the needs of the population for which the solution will be designed. It confirms (or rejects) the initial design goals as defined and determined by the design team based on community needs and resources. The process of obtaining validation can take many different forms, and it is often coupled with a community needs and resource assessment. The Mashavu team focused on four kinds of validation - concept validation, business plan validation, technology validation and usability validation. After the product has been designed, verification is performed to confirm that the design meets the operating requirements set forth at the onset of the design process. In other words verification refers to the correct completion of a design according to its specifications. Validation is distinct from verification as it seeks to answer the question "Are you building the right product?", whereas verification seeks to answer "Are you building the product right - as per the design specifications?"

Mashavu is a complex venture because it has many different users and stakeholders, various technology subsystems, and numerous potential applications. While the validation was primarily focused on understanding the healthcare aspects and how Mashavu integrated into that system, it is important to note that Mashavu operates alongside and within a number of other large systems that form the context of implementation. ${ }^{9}$

- Enabling Systems: Mashavu depends upon a number of enabling systems including the power (electricity) system, cell phone networks, and the Internet to perform its tasks.

- Legal Systems: Local doctors and Mashavu operators act in compliance with the healthcare policies and privacy norms in Kenya. 
International Journal for Service Learning in Engineering

Vol. 5, No. 1, pp. 1-24, Spring 2010

ISSN 1555-9033

- Education System: One of Mashavu's goals is to provide active community health education. The educational materials depend on the current education levels and attitudes amongst the people in the partnering communities.

- Healthcare System: Mashavu provides the community members with their first line of defense on health issues. It works alongside the existing healthcare system and requires the assistance of local doctors and doctors abroad.

- Social System: Social norms and power relations will determine the interaction of the Mashavu systems with the various stakeholders. For example, Mashavu will require the interaction between different genders in a medical setting.

- Business System: Mashavu is an entrepreneurial venture that is eventually going to be set up as a micro-enterprise. Micro-franchises are gaining popularity in Kenya: M-pesa and EkoToilet are two examples of successful ventures that are solving social problems and supporting livelihoods through microenterprise at the same time. The general population is also getting used to the concept of micro-payments, with cell phone credit being the most widespread micropayment made by millions of Kenyans every day.

It is important to determine how Mashavu would function with the various interacting systems. In order to do this, we attempted to understand the stakeholders and the impact of their actions on the Mashavu system. This understanding helped us uncover "sticky information" related to the societal context of the problems. Sticky information refers to information that is difficult to replicate and diffuse because it is embodied in the people, places, organizations, societal constructs, and other contextual entities. ${ }^{10}$ From a social science perspective, deconstructing the social situations that form the foundation of problems is important to get a better understanding of the context and the factors that help or hurt the implementation of the project. Deconstruction, in this sense, refers to the idea that there are multiple ways to analyze social situations. An understanding of this multiplicity can help expose the workings of various power relations in a given situation

Social deconstruction to uncover this sticky information and the root causes of the problem(s) might lead to factors outside the control of our team. However, the ways in which the basic problems and power dynamics interact and impact the project should be considered. The sticky information, including an understanding of the various power relations, helps identify key stakeholders, marginalized stakeholders, constraints and resources to be considered in the design process leading to sustainable solutions. ${ }^{10,11}$

\section{Coalition Building to Facilitate the Validation Process}

We had detailed discussions and sought feedback from our numerous contacts in East Africa, our colleagues familiar with healthcare challenges in Africa, and most importantly doctors and nurses in the U.S., Kenya and Tanzania. We assembled a team of students and faculty from Engineering, Health and Human Development, Business and Medicine to advance the project. The Humanitarian Engineering and Social Entrepreneurship (HESE) initiative at Penn State has several ongoing ventures in Kenya and Tanzania and we built on those relationships to negotiate specific roles and responsibilities for the various internal and external partners. 
International Journal for Service Learning in Engineering

Vol. 5, No. 1, pp. 1-24, Spring 2010

ISSN 1555-9033

Technology-based social entrepreneurial ventures are challenging, not so much because the technology is difficult to develop, but because making the technology work and sustain itself in the social and economic context of the partnering communities presents unique design challenges. To address some of the social challenges, we developed a collaborative program between Engineering and Women's Studies. The program brought together engineers, business people and social scientists and provided them with a compelling context to explore and appreciate the complexities of social problems and to develop, deploy, and assess innovative and practical technology solutions that create sustainable value for the partnering communities. ${ }^{11}$ Fourteen students participated in the three-credit professional seminar (Spring 2008) followed by a three-credit three-week internship in Tanzania (Summer 2008).

Five of the students from this class worked specifically on the Mashavu project. They represented a variety of disciplines including engineering, women's studies, political science, human development and family studies, biobehavioral health, film studies, and communications. They teamed up with 20 students (ages 19 to 30) from the United African Alliance Community Centre (UAACC) in Imbaseni, Tanzania. The Penn State students pitched the Mashavu concept to the UAACC students, who internalized it very quickly, and in about two hours the UAACC students were able to explain the Mashavu concept in English and Swahili (Figure 7). For three weeks, the 25 students engaged in various activities related to validation for Mashavu in and around communities in Imbaseni in Northern Tanzania.

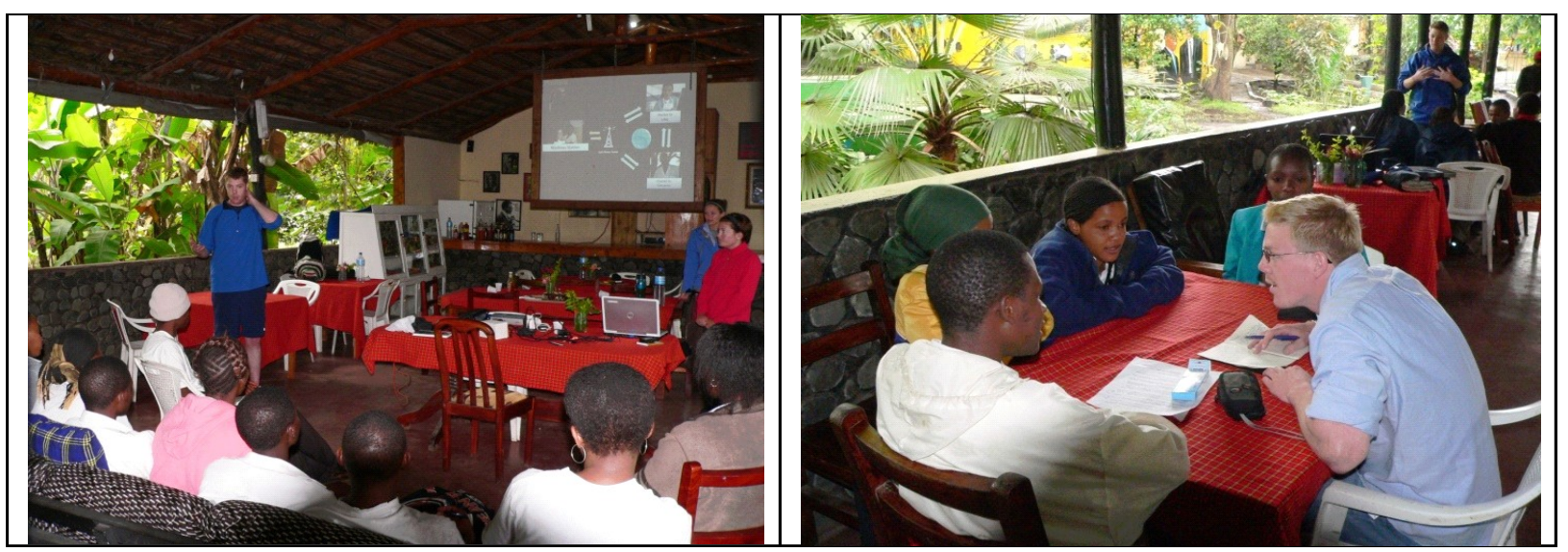

\section{FIGURE 7}

Students from Penn State University explain

Mashave to NeW team MEMbers at the UAACC

Ensuring equity from and between the various stakeholders involved in the project is critical to project sustainability and to instill a sense of pride and ownership. The primary challenge during business planning of social ventures for Base of the Pyramid (BOP) communities is finding the sweet spot between the time equity, money equity and sweat equity from the various stakeholders. This necessitates a complete understanding of the stakeholders and the kinds of equity they can invest in the 
International Journal for Service Learning in Engineering

Vol. 5, No. 1, pp. 1-24, Spring 2010

ISSN 1555-9033

venture. We sought a better understanding of the social environment that could lead us to marginalized stakeholders and resources not considered earlier. We engaged in various validation activities to uncover sticky information that would help us develop a business plan (equity scheme) that would create value for everyone and not reinforce traditional "winners" and "losers" or destabilize the power structure just to create new "winners" and "losers".

\section{Concept Validation}

Concept validation involved understanding whether the people in Tanzania understood, needed, and benefitted from a telemedicine system such as Mashavu. It was imperative that Mashavu solved a real, compelling problem for Tanzanians, and that it would make sense to implement it within the context. Validation of the concept was equally vital from both the patients' and doctors' perspectives. We sought to understand the stakeholders' comfort level and willingness to use Mashavu. Determining how Mashavu would fit in to the existing health care system and realizing the potential shortcomings and disruptions of the system was also essential.

\section{Business Plan Validation}

The goal for business plan validation was to determine if and how much people would be willing to pay for Mashavu services and what their expectations were. Issues like initial capital cost, recurring cost for data plans, electricity, and maintenance needed to be addressed in order to make Mashavu sustainable. Therefore, validating the accuracy of the potential cost structure would increase the likelihood of success for the first customers. Early success is very important in order to keep interest growing in the venture and reach a critical mass of participating doctors and patients. Additionally, we needed to validate that potential customers could get access to capital to purchase the Mashavu kiosk system.

\section{Usability Validation}

The focus of usability validation was to assess how easy or difficult it was for the various stakeholders to interact with and operate the system. We needed to assess how comfortable potential operatorsorphanage caregivers in this case-were with the technology including computers, biomedical devices, and cell phones. Although computers are becoming increasingly popular in rural areas, the number of people that are comfortable using them is very limited. Additionally, the use of biomedical devices is largely limited to trained nurses and doctors where as in the United States many more individuals are familiar with how to use devices that measure blood pressure, weight, and body temperature. Therefore understanding the usability issues involved in using Mashavu would provide our team with valuable data on how to design simple yet functional biomedical devices and kiosks.

\section{Technology Validation}

Gauging the availability of the primary and enabling technologies in the local area was the main focus. It was important to evaluate the availability and capability of computers, cell phones, cell phone networks capable of GPRS, power (electrical) systems and other technologies on which Mashavu 
International Journal for Service Learning in Engineering

Vol. 5, No. 1, pp. 1-24, Spring 2010

ISSN 1555-9033

relies. If these technology resources were not in place, the venture could not operate and sustain itself at an affordable price.

\section{On-The-Ground Data Collection}

A group of 25 students, comprised of 5 students from Penn State University and 20 students from the UAACC, worked together in small teams to seek answers to the questions described above. Each team had one Penn State student and four UAACC students. The Penn State students helped educate the UAACC students on the concept of Mashavu and determine what kinds of information was needed. In return, the UAACC students identified where to get answers and acted as translators between the Penn State students and the community members. The UAACC students contributed significantly to the Mashavu venture and provided a number of helpful insights, some of which are discussed in the next sections. The student teams worked in an intense, dynamic environment throughout the day and met every evening after dinner for an hour-long debriefing. During this meeting, the team discussed the research and planned the activities for the next day. Some of the activities that the student teams engaged in and the team's observations are summarized in the following sections.

\section{Clinic and Hospital Visits}

Our team visited three local clinics and hospitals - The University of Arusha Medical Center, Usa River Clinic, and Tengeru District Hospital - to gain intimate knowledge about the current health care system. These visits were unplanned and our teams were received graciously, despite not having an appointment to speak with nurses and doctors. This represented quite a difference from the United States where an unannounced visit would probably not be received so openly. We learned that the health care system in Tanzania is mostly a government-run, pyramid-shaped referral system (Figure 8). When someone is sick, they first visit a "local" primary care facility, or Health Center. If possible, the doctors or nurses will treat the patient. For more serious cases they will refer the patient to the next level of care, which is a district hospital. At the District Hospital, the same process occurs. If a patient cannot be treated there, they are referred to the Regional Hospital, and so on. The types of services and the complexity of the procedures that are offered at each level increases. Patients pay a small registration fee, and the government subsidizes treatment. 


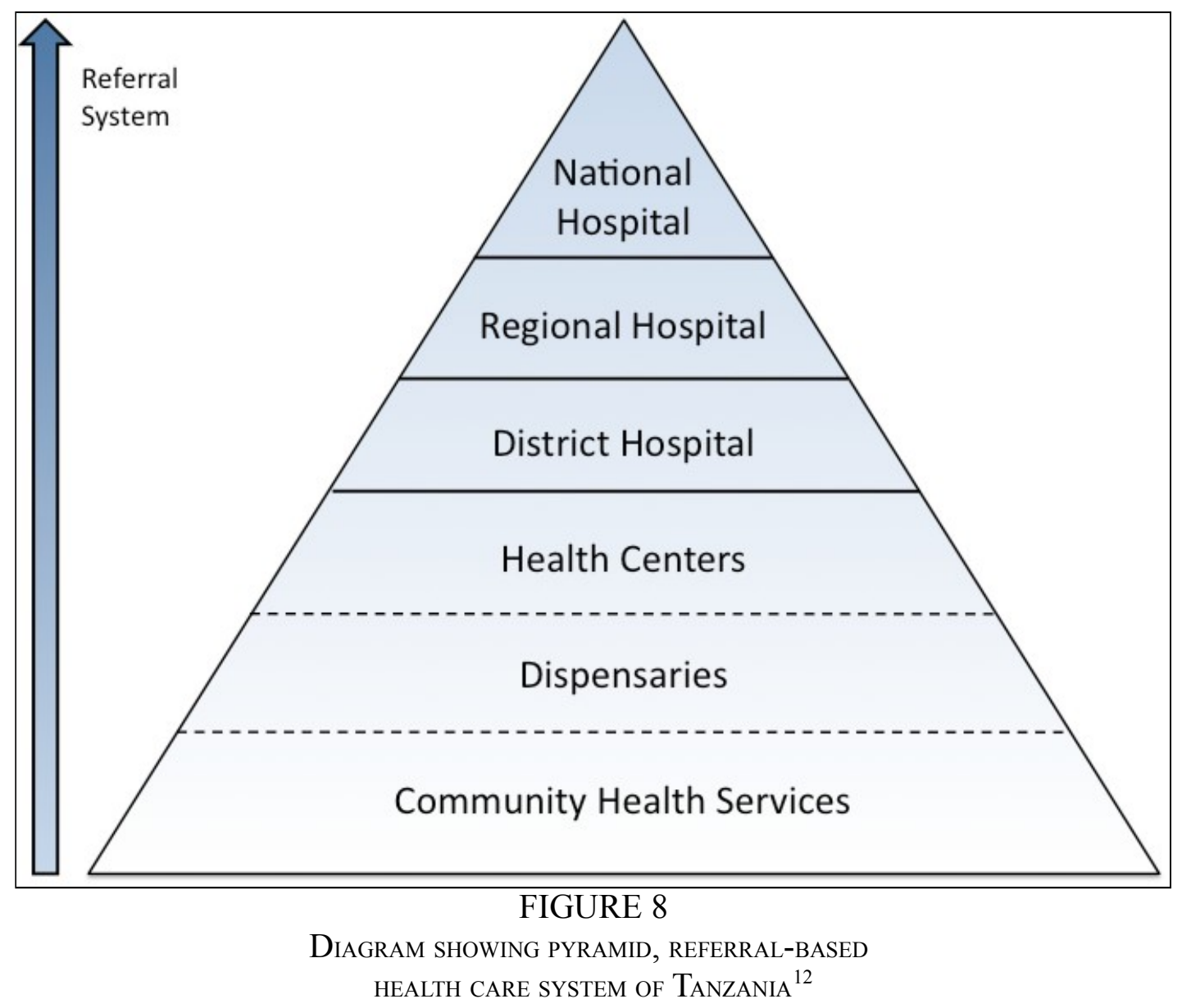

A private healthcare system exists alongside the public healthcare system. These private hospitals and clinics vary in the kinds of services they offer and where they are located. This has improved access to doctors and quality of service in some rural areas. However, these hospitals are more expensive than the public hospital system and still do not meet the need for health care at the community level. The University of Arusha (UoA) Medical Centre is a small privately-run primary care clinic. It is located on the University of Arusha campus, and it primarily caters to the students at the university, children at local primary and secondary schools, and employees of nearby Mt. Meru National Park. Many local community members also visit the clinic because it is the closest option (20 minutes on foot). Some services offered by the medical center are prohibitively expensive.

Usa River Clinic is a public, primary care facility in the town of Usa River, about 45 minutes from Imbaseni by dala-dala, or a three hour walk. This clinic sees a high volume of patients, many of whom travel from smaller surrounding communities. The Usa River clinic and the UoA Medical Centre offer a range of services including malaria treatment, maternity care, HIV/AIDS counseling, and hospice care. The team chose to visit the Usa River and University of Arusha clinics because they were closest in proximity and the first point of contact for people in this community. Tengeru district hospital is a public, secondary care facility located approximately one hour from Imbaseni by dala-dala. 
International Journal for Service Learning in Engineering

Vol. 5, No. 1, pp. 1-24, Spring 2010

ISSN 1555-9033

Almost all patients are sent to Tengeru via a referral from smaller primary care facilities such as the UoA Medical Center and Usa River Clinic.

To find out how the entire clinical process worked, from the earliest encounter through the point of contact with the district hospital, we had one of the UAACC students assume the role of a sick patient. Each step of the process was observed, and we explored many different medical scenarios. We also spoke to patients, doctors, and nurses about their personal needs for seeking or providing healthcare. Part of those discussions included how Mashavu could alleviate many of the challenges they face with healthcare. One noticeable trend at Usa River clinic was the significant role that women held in regards to healthcare. An overwhelming majority of the patients were women, often with children in tow. The clinic was busiest in the morning hours from $8 \mathrm{AM}$ to $10 \mathrm{AM}$. This was because many of these women had waited all night with their sick children until the dala-dalas started running in the morning. Tanzania is a patriarchal society, and women still uphold the traditional role of caregiver for the family. The ability to include women and children will be extremely important in the design and implementation of the system. Women might make a good choice as operators for the Mashavu kiosks.

At the UoA Medical Center, there was a lot of medical equipment--autoclaves, centrifuges, refrigerators, and washing machines - that was unused because it was broken. Most of this equipment had been donated, and the lack of spare parts, consumables, or trained repair technicians was to blame for the current state. This problem with medical equipment in developing countries has been well documented by the Engineering World Health program at Duke University, and the causes for those failures needs to be carefully considered in the design of the Mashavu system. ${ }^{13}$

While at Tengeru hospital, we learned that they already had a telemedicine system. This system was capable of doing Electrocardiograms (ECGs) and cost about \$7,000. The analysis of the ECGs was outsourced to a company in Rome, Italy - a very good example of reverse outsourcing! In talking with the personnel at the hospital, we also found that they were very eager to work with us, but they insisted on signing on a Memorandum of Understanding (MoU) before they would commit resources to the project. That was a very fair request by the hospital as they wanted to have the collaboration formalized and documented, and have the partner roles clearly defined. From our team's perspective, that was a roadblock because completing a MoU is a multi-step process and can often take several years and cost thousands of dollars. Without significant financial backing, it is very difficult to have the MoU in place. If a multi-dimensional partnership cannot be developed, the costs may not be worth it. Another concern our team had was the first-hand observation that for many organizations in developing countries, the MoU seemed like an internal metric of activities (or work) completed and hence the endpoint of the collaboration.

Indigenous knowledge played an important role in the healthcare system. The head doctor at the UoA Medical Centre estimated that around $80 \%$ of the local villagers utilized traditional healers in some manner. This number was surprisingly high, and it indicated that traditional medicine was used in concurrence with modern medicine by a large percentage of the population. At Usa River, the nurses were using honey as an antiseptic. This practice had long been used because it was effective, available, and inexpensive. Including traditional medicine and indigenous knowledge into the design or implementation of Mashavu could improve the success of the venture. 
International Journal for Service Learning in Engineering

Vol. 5, No. 1, pp. 1-24, Spring 2010

ISSN 1555-9033

Medical records at all of the facilities were kept in paper notebooks and binders stacked in bookshelves. Anyone could easily walk over and look through them. Patients were also more than willing to talk about their health problems with us in public, and the doctors eagerly showed us around the facilities. This highlighted the difference in maintaining medical records in Tanzania compared to Western countries. The concept of patient privacy was not emphasized as much as the United States. While privacy is certainly a concern and something we look to instill in the project, we found that it would not be a major roadblock towards development and implementation of Mashavu. We found that liability was also viewed in the different manner and the concept of suing entities for malpractice was practically nonexistent. This was important because much of the feedback our team received prior to traveling was that we lacked sufficient emphasis on privacy and liability, at least from a Western perspective. A major challenge that emerged was how to handle accountability and to design a system with adequate checks and balances to make sure that all the stakeholders actually do what is expected of them. This issue has been explored in significant depth in a more advanced paper that focuses on applying systems thinking to make such ventures more realizable and sustainable. ${ }^{9}$ Our team is also developing a uniform concept of operations for all the stakeholders. The idea is to standardize the process, similar to the Aravind eye hospital in India or the process of ordering a sandwich at any Subway location anywhere in the world.

Overall, the doctors and nurses were very enthusiastic about Mashavu. The clinics even expressed interest in owning a Mashavu kiosk to assist with check-in and triage of patients. We were astonished to find the Tanzanian clinics use the same family of biomedical devices as the expensive offthe-shelf telemedicine devices used in the United States. This showed that the system had value even without an Internet connection. The doctors at the UoA Medical Centre informed us that the best time to pilot the system was in May and June because the doctors and nurses would have more availability. This was because the students at the university were on break during that time, and the incidence of malaria was less during those months. One concern voiced by the doctors was the ability to trust the person operating the Mashavu kiosk to properly work the devices and interpret the doctor's responses.

\section{Community Surveys}

After visiting the clinics, the team wanted to talk with more community members in order to understand their healthcare needs and how they might relate to Mashavu. To accomplish this, we split into two small groups of 3-4 students. The Tanzanian team members explained the functionality of the Mashavu system to the community members. After spending about five to ten minutes explaining the system, each community member was asked five questions:

- What are the primary diseases/health problems in this particular area?

- Do you have any chronic illnesses?

- Do you use traditional medicine or modern medical practices?

- Do you think Mashavu will work well in this location?

- How much would you be willing to pay to access this system?

The majority of people who were surveyed responded with positive feedback and answers that would support the demand for a Mashavu system in their area. The top five reasons for seeking medical care were malaria, Acute Respiratory Infections (ARIs), pneumonia, skin infections and diarrhoereal 
International Journal for Service Learning in Engineering

Vol. 5, No. 1, pp. 1-24, Spring 2010

ISSN 1555-9033

diseases, and $45 \%$ reported that they had chronic health problems like diabetes, hypertension and lung problems. It was reassuring to see that most common problems such as acute respiratory illness, and skin and eye infection, could be addressed by Mashavu. The approximately 200 people indicated that they were willing to pay an average of $1380 \mathrm{TSh}$, or about \$1.2 USD, to use the Mashavu system.

\section{Magiza - A Swahili Play}

While the community surveys were highly effective, a challenge the team encountered was that they were only able to speak with the head(s) of the household. This was typically the eldest male. Women and children, who are critical stakeholders for the Mashavu project, were not being included in this vital survey in most circumstances. In order to address the lack of critical feedback from women and children in the community, the team brainstormed on various ways to include this demographic. Our team realized that holding formal meetings was not the most effective way to correct this issue. Rather, the UAACC students suggested that we develop a skit, called a 'magiza' in Swahili. A magiza is a popular form of communication in Tanzania because their informal style and inclusive nature draws the attention of every group in the community. By communicating in this unique manner, we were able to connect with various audiences in a way that would maximize their attention and enable us to receive feedback from them.

To develop the Mashavu magiza, fifteen students from Penn State and UAACC worked together to create a 30-minute skit in English and Swahili (Figure 9). The three-act play consisted of the basic concepts surrounding general health, what happens when body parameters go out of range, and the functioning of the Mashavu system simulated by a real case. The play was performed by the team at various local schools, orphanages and community centers including the Mount Meru Peak Primary School, the Good Hope Orphanage, and the UAACC. At the end of the play, the audience was invited to ask questions about Mashavu and offer their insights. By incorporating indigenous knowledge and molding our initial ideas to the context, the team was able to access key members of the population. 


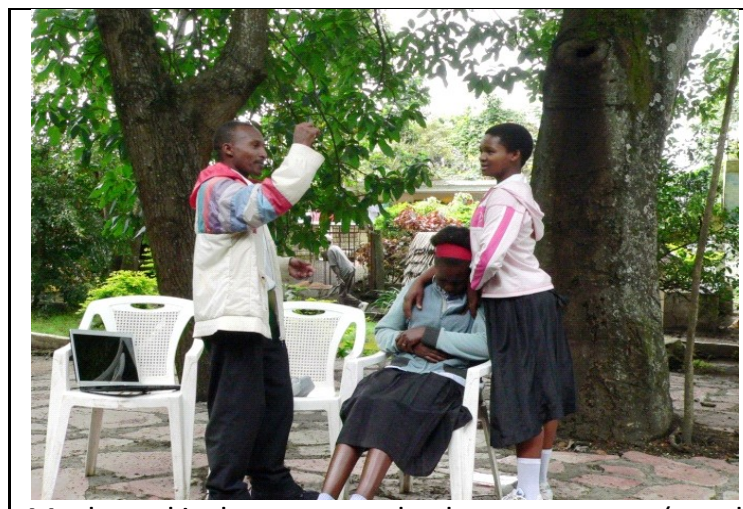

Mashavu kiosk operato $r$ checks temperature (a nd other vitals) of sick child while mother watches

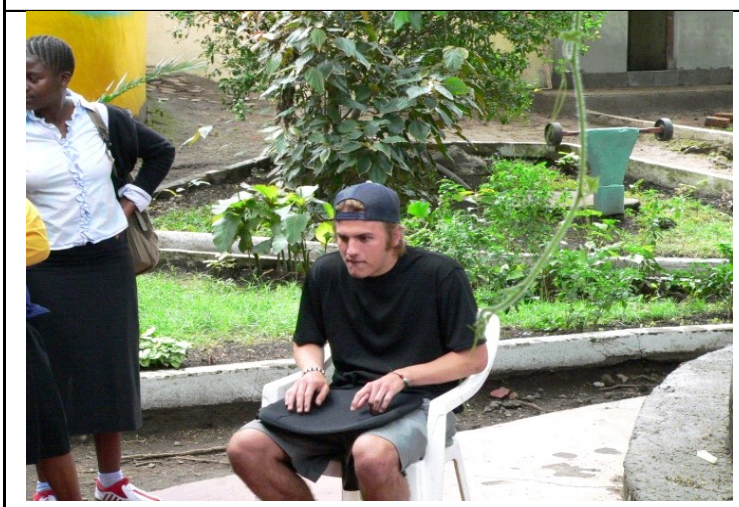

Dr. Milnes gets alert, reviews info and

recommends visiting doctor immediately. He also sends info and recommendations to nearest clinic. Child is taken to the nearest clinic - an hour's walk away.

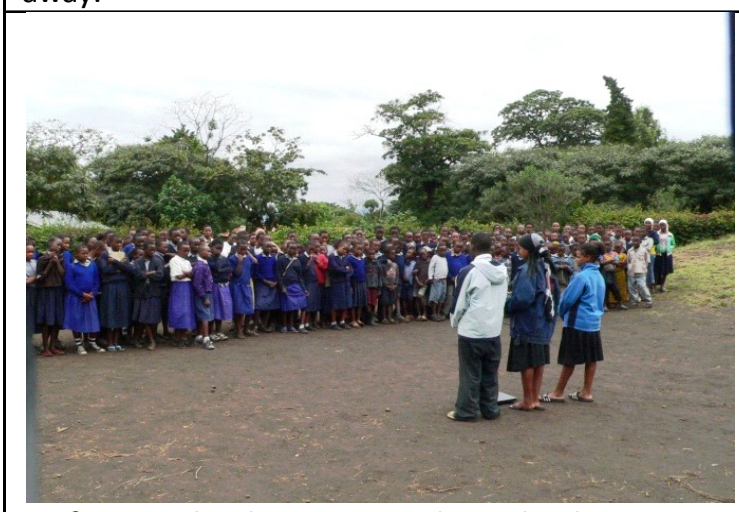

Performing the skit at a secondary school

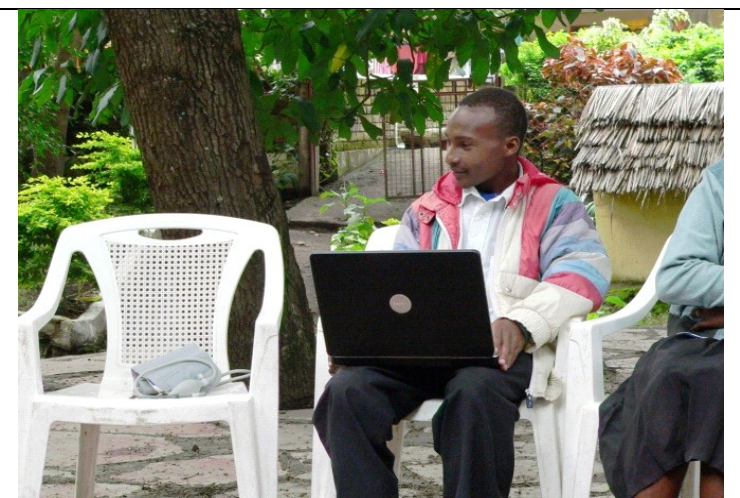

Kiosk operator enters info on Mashavu station which is immediately posted on web portal. An alert is sent to Dr. Milnes .

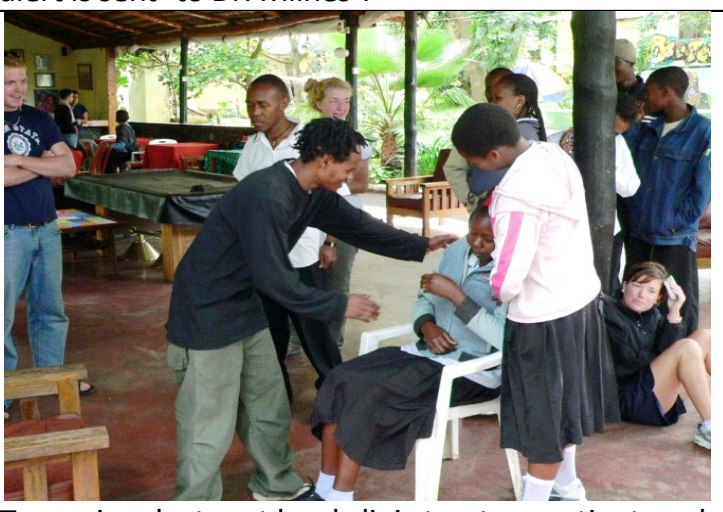

Tanzanian doctor at local clinic treats she becomes healthy again.

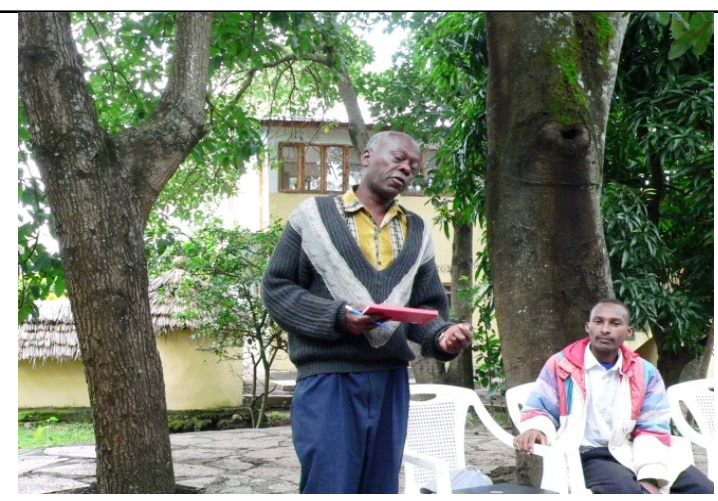

One of our local champions addressing the crowd after the skit and asking questions.

FIGURE 9

The Mashavu team Performing the Magiza (skit) 
International Journal for Service Learning in Engineering

Vol. 5, No. 1, pp. 1-24, Spring 2010

ISSN 1555-9033

During one of these plays, we encountered a local community member who also taught at UAACC. It was apparent that he was a well-respected member of the community and therefore had an excellent connection with the neighboring communities. He truly understood and believed in what we were trying to do, and eagerly agreed to become our local champion. His efforts helped us connect and communicate with the village elders. We realized the importance of having local champions and opinion leaders on our side during the validation as well as implementation phase of the venture. We discovered that women were very interested in operating small businesses as an income-generating activity. Since we were considering women as potential system operators, we were glad to hear about their entrepreneurial ambitions. The men were also supportive of their spouses operating Mashavu as a small business because then the women could work from home and look after the children and household while making money at the same time.

Following the magiza at Good Hope Orphanage, several Penn State students met with the caregivers to conduct training and usability testing. The caregivers at the orphanage were middle-aged and older women who had never before used computers or biomedical devices like a blood pressure device and weighing scale. The caregivers were able to easily interact with the computer and navigate the graphical user interface for the Mashavu kiosk (Figure 10). The students taught them how to take the blood pressure and weight of several children. Within 15 minutes, the women had learned how to use the computer program and were teaching each other. They were not afraid to use the technology. Technology is traditionally considered a male-gendered object, while health is traditionally femalegendered in Tanzania, yet these women were perfectly willing and excited about using the new technology. Most of all, their eagerness to learn was incredibly encouraging.

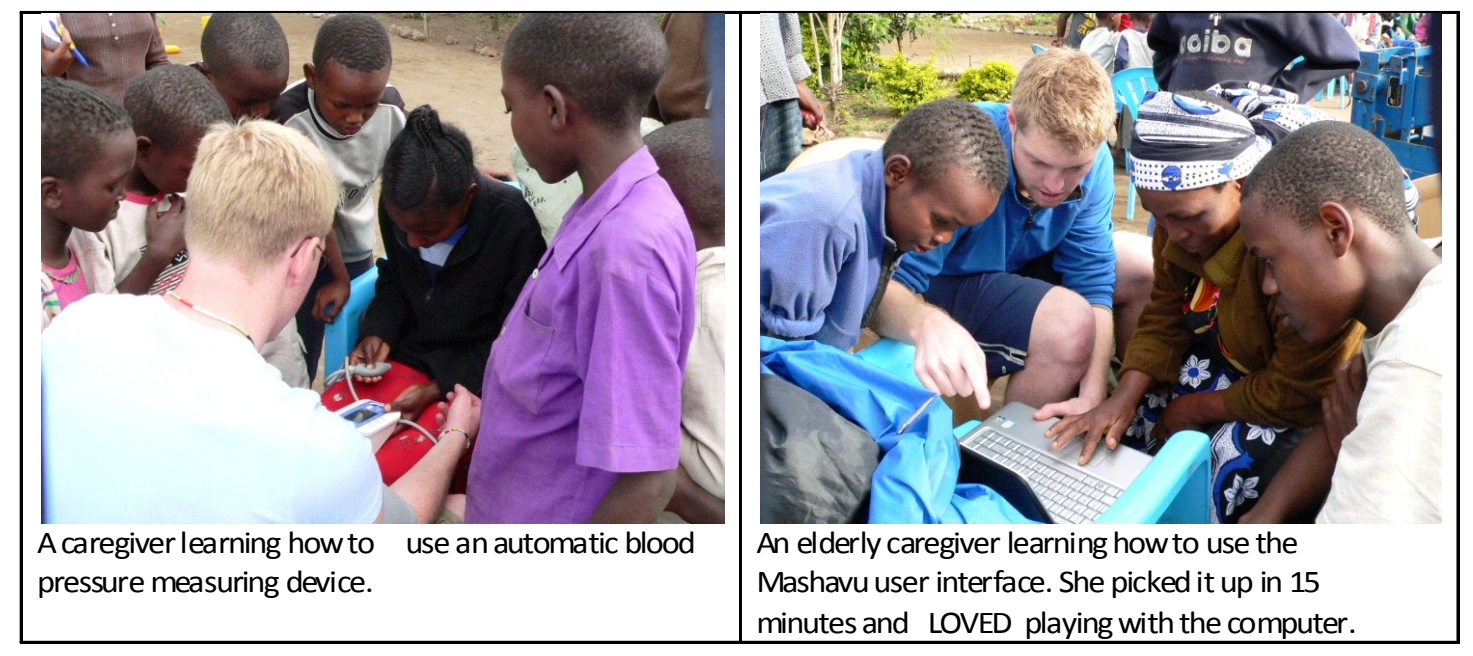

FIGURE 10

A caregiver at Good Hope Orphanage learns HOW to OPERATE THE MASHAVU SYSTEM 
International Journal for Service Learning in Engineering

Vol. 5, No. 1, pp. 1-24, Spring 2010

ISSN 1555-9033

\section{Tamashaa - A community festival}

The Mashavu team was invited to a local community festival called a 'tamashaa' in Swahili. The tamashaa had live music, food, games, HIV/AIDS awareness campaigns and various other activities. We set up a Mashavu kiosk at the tamashaa with a commercial off-the-shelf blood pressure device and a weighing scale. The UAACC students operated the devices and queues instantly formed around the makeshift kiosk, as curiosity prompted most individuals to stop by (Figure 11).

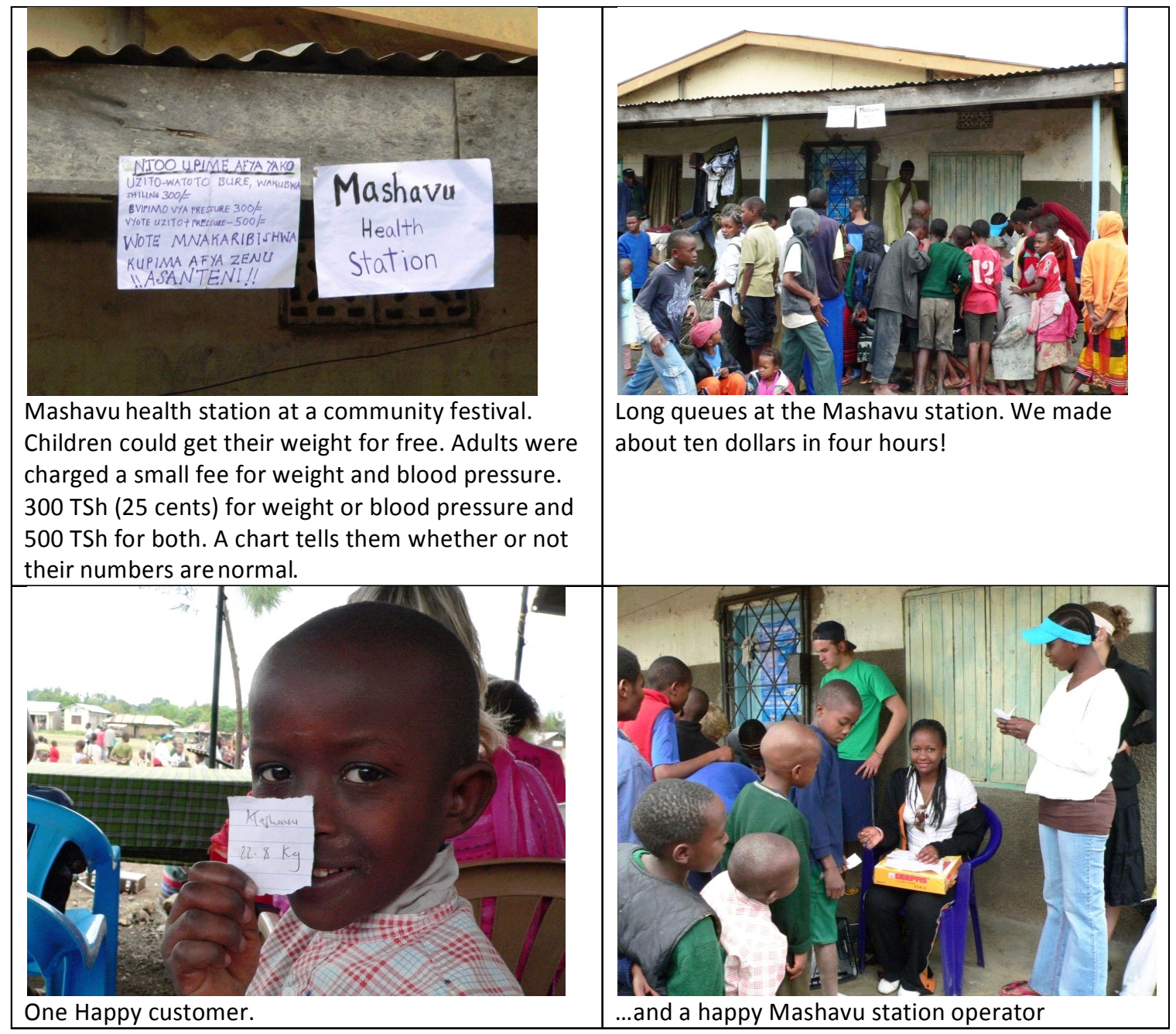

FIGURE 11

The Mashavu Health KIOSK at the Tamashaa

While we had received prior feedback from the community surveys that people would be willing to pay for the services that Mashavu offered, the ultimate validation is the completion of a transaction. Therefore, we decided to charge the community members a small amount of money to 
International Journal for Service Learning in Engineering

Vol. 5, No. 1, pp. 1-24, Spring 2010

ISSN 1555-9033

provide them their blood pressure and weight. The majority of our customers were children that received their weight free of charge. We discovered that the children as well the adults were expecting something tangible when they were visiting Mashavu - a piece of paper with their numbers on it worked just fine!

Adults were charged a small fee: 300 TSh ( 25 cents) for weight or blood pressure and 500 TSh for both. A chart informed them whether or not their numbers were within average ranges. The team made a total of about ten dollars in four hours. Given the fact that we did not do any marketing, that was excellent validation that people were willing to pay for the service. Some of our customers were there partially due to the novelty factor but many of the people understood the importance of monitoring their blood pressure or were aware that they suffered from hypertension. They were glad to get their blood pressure for 300 TSh because it saved them a trip to the doctor. An interesting situation the team encountered while at the Tamashaa was when an elderly woman wanted to know her blood pressure but did not have the money to pay for it. We learned that it was very typical for elderly people (especially women) to not have money to pay. Nevertheless, these women did participate in the local informal economy (e.g. looking after children in exchange for food). This led us to pose many important questions such as: What kind of equity can these women (and others in a similar situation) contribute and how can Mashavu address their needs? This incident and the interesting questions it raised proved extremely important for the next iteration of the business plan and the system as a whole.

There were some women who had been told they had high blood pressure, but they did not have it recently measured. This indicated a higher level of health awareness for some of the population. But, most people did not know what their blood pressure was or what it meant in regards to their health. The challenge was to both quantify their blood pressure and explain the meaning of those numbers. Part of the reason that blood pressure is a little-known concept is that devices to measure blood pressure are not found outside of clinical settings. Just like people in the U.S. wouldn't have a CT scan machine at home, people in Tanzania would not have a blood pressure device at home! Our team members also discovered that it was common to find micro-entrepreneurs with weighing scales in urban areas and community centers. These people would charge a small amount of money for people to know their weight. This business model has been used successfully in many places including India, China, Jordan and Turkey (Figure 12). 


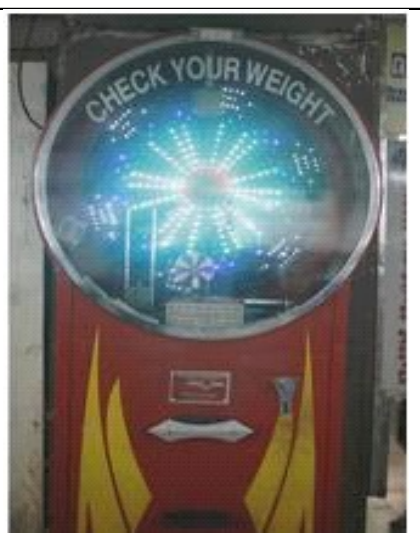

Weighing machine in Mumbai, India. For 5 cents it will tell you your weight (and fortune).

This has been around for decades!!!

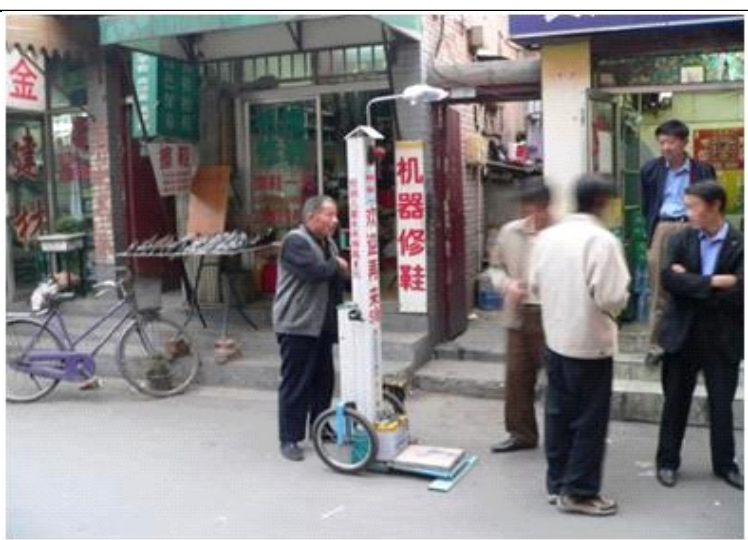

Weighing machine and height detector in Beijing, China. The system runs from a car battery. There is a simple weighing scale and a mot orized system that comes down till it touches your head...and you have your height.

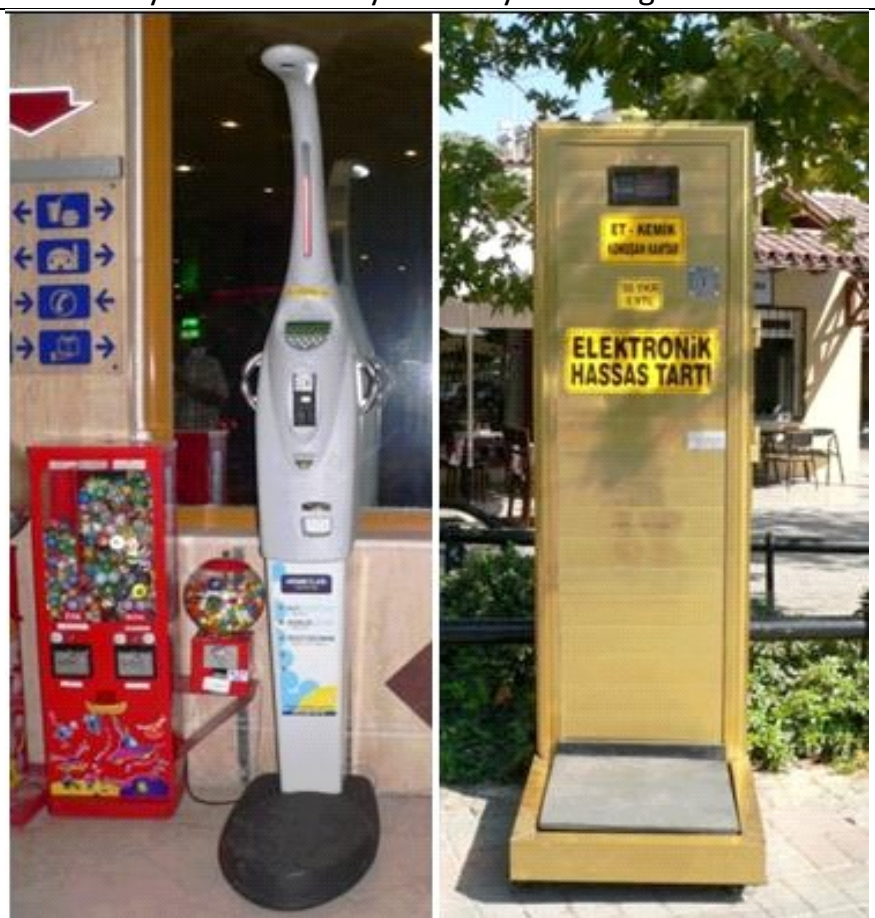

Height/weight machines at $v$ arious places in T urkey. The one on the right charge $s$ almost a dollar to give you your weight!
This machine in A mman, Jordan gives you your height and weight for about 50 US Cents
FIGURE 12

$P_{A y} P_{\text {er }} U_{\text {se }} W_{\text {EIGHing }}$ Scales Around the World 
International Journal for Service Learning in Engineering

Vol. 5, No. 1, pp. 1-24, Spring 2010

ISSN 1555-9033

\section{Local Town Visits/Resource Assessment}

To validate the availability of primary and enabling technologies, as well as the services that support them, our team evaluated local resources available in the Imbaseni area. We visited the market areas of Usa River and the commercial hub of Arusha, 45 minutes away. In regards to electronics, we found multiple shops that sold electronic equipment, such as wires, soldering equipment, and other simple circuit components. We also saw several stores in Arusha that sold computers, computer components, and did some computer repairs. Another prevalent shop was one where people could take their cell phones to get them unlocked, flashed, or repaired. This displayed that there were people in the area who were capable of learning technical skills with regards to electronics and that there is potential for these services to be adapted to the Mashavu system.

Computers were present in many of these developing communities. Most of these computers were recycled desktop computers in various states of functionality. Most were being utilized a lot less than they could have been. Desktops consume much more power than laptops and netbooks. Additionally, they don't have any battery to use when power goes out. Electricity is an important issue as brown outs happened almost daily. Cell phones were not an issue. Additionally, coverage maps for local carriers covered many rural areas.

\section{Conclusion and Future Plans}

Uncovering the "sticky" information of the context helped our team to understand the problem better. Working with people on the ground facilitated the validation process. The validation and feedback we received has been critically analyzed and incorporated into the design process. The importance of fun, instant gratification in the entire process, and appropriate design of the clinical encounter were larger themes that emerged during the validation process. The validation activities also revealed the importance of educating all our stakeholders about Mashavu to make the system usable and sustainable and have a larger impact on the partnering communities. We discovered that challenges and dynamics even in neighboring communities were fairly distinct. A flexible, yet uniform, Code of Ethics and compliance mechanisms were necessary so that Mashavu can scale up in an organic manner. ${ }^{14}$ The validation we received from the research in Tanzania gave our team a clearer path forward. Since then, over 150 students and several faculty members have participated in the Mashavu project over the last two years. The first design iteration was held in the 2008-2009 academic year with field-testing conducted in Kenya during Summer 2009.

The second phase (currently underway) entails refining the technology and conducting a full scale pilot-test of the Mashavu kiosk and network with various clinics and child-care facilities including our current partner, Children and Youth Empowerment Center - a public-private entity with a number of centers that care for former street-dwelling children in Kenya. The United Nations Industrial Development Office (UNIDO) has a large project called "Lighting up Kenya" focused on alternate energy kiosks in remote areas. The African Medical Research Foundation (AMREF) has telemedicine systems to connect rural and urban clinics but needs inexpensive diagnostic technology to reach patients in rural communities. Mashavu presents a perfect symbiotic relationship with these existing programs and hence UNIDO and AMREF are very interested in partnering with us. These are all very 
International Journal for Service Learning in Engineering

Vol. 5, No. 1, pp. 1-24, Spring 2010

ISSN 1555-9033

exciting developments but we believe that we have made as much progress on the design of an appropriate system because we specifically focused on validating the concepts and charting the course of action based on the sticky information gathered during the initial validation phase.

\section{ACKnOWLedgment}

The authors are grateful to all the students, faculty members and community members who are collaborating on this ambitious venture. The authors would also like to thank the Jimmy \& Rosalynn Carter Partnership Foundation (JRCPF) for supporting the validation phase of the project through a Carter Academic Service Entrepreneur (CASE) grant. The other sponsors for this venture include National Collegiate Inventors \& Innovators Alliance (NCIIA), Ideablob, and National Instruments.

\section{REFERENCES}

1. Mehta, Khanjan, and Thomas Colledge. Humanitarian Engineering and Social Entrepreneurship, 2010. Online. $<$ http://www.engr.psu.edu/hese $>$.

2. Mehta, Khanjan, Mary Lynn Brannon, Sarah Zappe, Thomas Colledge, Yu Zhao, "eplum Model of Student Engagement: eplum Model of Student Engagement: Expanding non-travel based Global Awareness, Multidisciplinary Teamwork and Entrepreneurial Mindset Development." Proceedings of the ASEE Annual Conference. Louisville, Kentucky: ASEE, 2010.

3. WHO Statistical Information System (WHOSIS). World Health Organization, 2009. Online. $<\underline{\text { http://www.who.int/whosis/en/>. }}$

4. "State of the World's Children 2009: Maternal \& Newborn Health." United Nation's Children's Fund (UNICEF). New York : UNICEF, 2009. pp. 132-133, Annual Report. 978-92-806-4318-3.

5. Hancock, Simon. "Mobile phones boom in Tanzania." BBC News Online. 22 July 2005.

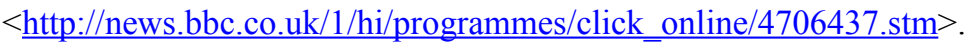

6. Mark, Okuttah. "Computer firms bet on Netbook to expand reach and grow sales." Business Daily Africa. 1 Dec 2009. < http://www.businessdailyafrica.com/Company Industry//539550/815262/-/t6g6sxz/-/index.html > .

7. "Work in the Field - Frequenty Asked Questions." Doctors Without Borders. 2009. $<$ http://doctorswithoutborders.org/work/field/faqs.cfm - length>.

8. Wootton, R. Telehealth in the Developing World. Ottawa, ON: International Development Research Centre, 2009. Online.

9. Stepler, Renee, Steve Garguilo, Khanjan Mehta, Sven Bilen. "Applying Systems Thinking for Realizing the Mission of Technology-based Social Ventures in Africa." American Society for Engineering Education: Proceedings of the ASEE Annual Conference. Louisville, Kentucky, 2010

10. Von Hippel, E. “'Sticky Information' and the Locus of Problem Solving: Implications for Innovation.” Management Science, 1994.

11. Mehta, Khanjan., Nicole Laliberte, Aaron Fleishman, Julia Wittig, Lee Ann De Reus, Lorraine Dowler. "Multidisciplinary Social Entrepreneurship Education Model: If Capitalism, Socialism and Feminism in concert strive, will Social Entrepreneurship thrive?" National Collegiate Inventors and Innovators Alliance (NCIIA) Annual Meeting Proceedings, Washington, DC, 2009.

12. "Health Services System (Structure)." The United Republic of Tanzania Ministry of Health and Social Welfare. 2005. Web. 17 Mar. 2010. <http://www.moh.go.tz/health services.php>.

13. Malkin, Robert A. "Design of Health Care Technologies for the Developing World." Annual Review of Biomedical Engineering, September 2009: 567-87.

14. Turner, Chanda, Khanjan Mehta. "Development of Code of Ethics for a Social Entrepreneurial Telemedicine Venture in Kenya". NCIIA Annual Meeting, San Francisco, March 2010 